\title{
Breast Cancer and Personal Environmental Risk Factors in Marin County - Pilot Study
}

Erdmann $\mathbf{C A}^{1}$, Farren $\mathbf{G}^{2}$, Baltzell $\mathbf{K}^{3}$, Chew $\mathbf{T}^{3}$, Clarkson $\mathbf{C}^{2}$, Fleshman $\mathbf{R}^{3}$, Leary $C^{2}$, Mizroch $M^{3}$, Orenstein $F^{2}$, Russell $M^{1}{ }^{1}$, Souders-Mason $V^{2}$, Wrensch $\mathbf{M}^{3}$

${ }^{1}$ Lawrence Berkeley National Laboratory

${ }^{2}$ Marin Breast Cancer Watch

${ }^{3}$ University of California San Francisco

Report submitted to the

Marin County Department of Health and Human Services

Address correspondence to:

C. A. Erdmann, Ph.D., MPH

Mailstop 90-3058

Lawrence Berkeley National Laboratory

One Cyclotron Road

Berkeley, CA 94720

U.S.A.

\section{February, 2003}

This work was made possible by funds received from the Centers for Disease Control and Prevention administered through the Marin County Department of Health and Human Services. This project was also partially supported by the Susan Love MD Breast Cancer Foundation. 


\section{DISCLAIMER}

This document may contain research results which are experimental in nature. Neither the United States Government, nor any agency thereof, nor The Regents of the University of California, nor any of their employees, makes any warranty, express or implied, or assumes any legal responsibility for the accuracy, completeness, or usefulness of any information, apparatus, product, or process disclosed, or represents that its use would not infringe privately owned rights. Reference to any specific commercial product, process, or service by its trade name, trademark, manufacturer, or otherwise, does not constitute or imply an endorsement or recommendation by the United States Government or any agency thereof, or by The Regents of the University of California. The views and opinions of the authors expressed herein do not necessarily state or reflect those of the United States Government or any agency thereof, or by The Regents of the University of California and shall not be used for advertising or product endorsement purposes. 


\section{ATTRIBUTION}

Cancer incidence data used in this study have been collected by the Northern California Cancer Center under contract N01-CN-65107 National Cancer Institute, National Institutes of Health, and with support of the California Cancer Registry, a project of the Cancer Surveillance Section, California Department of Human Services, under subcontract 050N-8701/8-S1522 with the Public Health Institute. The content of this publication does not necessarily reflect the views or policies of the US Department of Health and Human Services, nor does mention of trade names, commercial products, or organizations imply endorsement by the US Government. 


\section{ACKNOWLEDGEMENTS}

This pilot study was made possible, not only by its team members, but also by those who dedicated their time and resources to assist the project. Dr. Kay Flink, from the Marin County Public Health Laboratory in San Rafael, graciously offered use of her facility's freezer for specimen storage. Kathy Koblick and Rochelle Ereman from the Marin County Department of Health and Human Services facilitated distribution to all county employees of flyers about PERFS' community workshops and greatly increased the project's visibility. Joe Klimmeck and Karen Walters were invaluable in entering the volumes of data generated by the community workshops and study questionnaires. Dr. Regine Goth-Goldstein provided invaluable advice concerning the gene expression analyses. Dr. Joe Gray and Dr. David Ginzinger permitted us emergency access to their RT-PCR instrument at UCSF for specimen analysis. Lastly and most importantly, thank you to all participants in the study, especially all of the volunteers who helped our staff gain experience with the NAF protocol. 


\section{CONTENTS}

Introduction, 6

Literature Review, 7-9

Community Input \& Evaluation, 9-14

Questionnaire Development \& Evaluation, 15-19

Buccal Cell Collection, 19

Nipple Aspirate Fluid Collection \& Evaluation, 20-21

Nipple Aspirate Fluid Analysis, 21-25

Discussion, 25-26

References, 26-30

Appendix A, 31-33

Appendix B, 34-36 


\section{INTRODUCTION}

The purpose of the Personal Environmental Risk Factor Study (PERFS) pilot project was to develop methodologies and a questionnaire for a future population-based case-control study to investigate the role of selected environmental exposures in breast cancer development. Identification of etiologically relevant exposures during a period of potential vulnerability proximate to disease onset offers the possibility of clinical disease prevention even when disease initiation may have already occurred many years earlier. Certain personal environmental agents or combinations of agents may influence disease promotion. Therefore, this pilot study focused on exposures that occurred during the ten-year period prior to diagnosis for cases and the last ten years for controls, rather than more historic exposures.

For this pilot study, we used a community-based research approach. In our collaborative efforts, community members participated with academic researchers in all phases of the research, including research question identification, study design, development of research tools, development of the human subjects protocol, and report writing. Community member inclusion was based upon the concept that community participation could improve the relevance of scientific studies and ultimate success of the research by encouraging an ongoing dialogue between community members and academic representatives. Early activities of this project focused on the collection of input from the community regarding the possible role of environmental factors in the incidence of breast cancer in Marin County. The intent was to inform the scientists of community concerns, enhance the research team's understanding of the community being studied, and provide interested community members with a better understanding of the strengths and weaknesses of traditional research methods through active participation in the research process.

This pilot study identified specific testable hypotheses through review of the literature and consultation with relevant experts and the affected community. Initially, the study was to focus on modifiable personal environmental exposures that are associated with breast tumor promotion and higher socioeconomic status (SES). However, little information was available in the scientific literature regarding the putative mechanism by which some of the suspected environmental factors may act (i.e., initiator vs. promoter). Likewise, little is known about the distribution of personal environmental risk factors by socioeconomic status. Therefore, tumor promotion involvement and association with SES were not very useful as selection criteria, and selection of topics was based primarily on published scientific findings of human studies and community input.

This study was approved by the Institutional Review Boards at the University of California at San Francisco (Committee on Human Research) and at the University of California at Berkeley (Committee for the Protection of Human Subjects).

\section{LITERATURE REVIEW}

Initial Review. PubMed (www.pubmed.gov) and the Computer Retrieval of Information on Scientific Projects (CRISP) website (crisp.cit.nih.gov) were searched for studies on personal 
environmental risk factors and breast cancer risk, placing particular emphasis on modifiable factors associated with socioeconomic status and tumor promotion. Specifically, we searched PubMed on the keywords "breast cancer environment review" through December 2002. The retrieved PubMed records were then manually reviewed for relevant articles. Initially, the Computer Retrieval of Information on Science Projects (CRISP) database was searched using the following parameters: keywords, "breast cancer environment"; years, 1998-2002; all institutes; all states; global logic, "and". The retrieved CRISP records were manually reviewed for relevant projects. Reports from the community-based studies conducted in Long Island, NY (The Long Island Breast Cancer Study Project) and Massachusetts (The Newton Study and the Cape Code Study by the Silent Spring Institute) were obtained and reviewed. Other articles were also included as appropriate to provide background information. We manually searched selected websites and publications for relevant articles. Academic and community collaborators both participated in reviewing the literature. A list of background readings considered by the study group appears in Appendix A.

Factors Selected for Detailed Study. Based upon the initial literature review, discussions with other researchers, community input, review of preliminary results from other studies in Marin County, and feasibility of study in a case-control design, several factors were selected for more detailed study. For the future population-based case-control study, we will focus on known and probable, modifiable breast cancer risk factors (i.e., alcohol, physical activity, oral contraceptives, and hormone replacement therapy) as well as suspected modifiable environmental risk factors (i.e., polycyclic aromatic hydrocarbons and light-at-night). The peerreviewed literature pertaining to the key selected factors is summarized below.

Alcohol use and associated modifiers. While the influence of alcohol intake on breast cancer risk has been controversial, substantial evidence consistently supports a modest positive association (Hankinson \& Hunter, 2002; Hamajima et al., 2002; Horn-Ross et al., 2002; Rosenberg et al., 1993; van't Veer et al., 1989; Young, 1989; Katsouyanni, 1994). Reported relative risks have ranged from $1.1(95 \% \mathrm{CI}, 1.1-1.2)$ for one drink per day to $3.3(95 \% \mathrm{CI}, 1.2-$ 9.3) for greater consumption (Longnecker, 1994; Hunter \& Willett, 1993). Alcohol may influence circulating hormone levels, possibly increasing estrogen levels in circulating blood, which have been found to be associated with increased breast cancer risk (Reichman et al., 1993; Thomas et al., 1997). Other possible mechanisms include a direct carcinogenic effect of alcohol metabolites (e.g., acetaldehyde) (Ames, 1983) and an antagonistic effect on folate metabolism (Zhang et al., 1999). High intake of folic acid may reduce the breast cancer risk associated with alcohol intake (Zhang et al., 1999). Both early and proximate alcohol intake have been found to be associated with breast cancer risk (Harvey et al., 1987; Longnecker et al., 1995). Two studies have shown good reliability of alcohol intake histories (Longnecker et al., 1992; Giovannucci et al., 1993).

Physical activity. Epidemiologic studies of the association between physical activity and breast cancer risk have yielded inconsistent results (Hankinson \& Hunter, 2002). Some have attributed this inconsistency to differences in assessment methods used and time periods studied (Gammon et al., 1998). Physical activity may influence breast cancer risk through alteration of menstrual cycle patterns, maintenance of healthy weight, reduction of serum estrogen levels, and improved immune function (Gammon et al., 1998). Strenuous activity can delay onset of menarche and increase the frequency of anovulation (Willett et al., 200). Using a very detailed physical activity assessment, Bernstein et al. (1994) found that premenopausal women who, on 
average, spent 3.8 or more hours per week engaged in physical exercise activities experienced a $58 \%$ reduction in breast cancer risk $(\mathrm{OR}=0.42 ; 95 \% \mathrm{CI}, 0.27-0.64)$.

Oral contraceptive use. Though most epidemiologic studies have not found a statistically significant association between breast cancer risk and duration of oral contraceptive use, studies of current and recent use suggest that oral contraceptives may act as late-stage promoters (Hankinson \& Hunter, 2002). In a re-analysis of data from 54 studies with a combined total of 53,297 women with breast cancer and 100,239 women without breast cancer, the Collaborative Group on Hormonal Factors in Breast Cancer (1996) found a small increase in risk among current users of combined oral contraceptives and in women who had stopped use within the past 10 years $(R R=1.24)$. Among women who had stopped use for more than 10 years, there was no observed increase in risk. A more recently published cohort study of 103,027 Swedish and Norwegian women reported a similar finding for current/recent oral contraceptive use versus never users (RR $=1.6 ; 95 \%$ CI, 1.2-2.1) (Kumle et al., 2002).

Hormone replacement therapy use. Postmenopausal hormone use is a well-confirmed breast cancer risk factor (Hankinson \& Hunter, 2002). A pooled analysis of 51 epidemiologic studies by the Collaborative Group on Hormonal Factors in Breast Cancer (1997) found that each year of current or recent hormone replacement therapy (HRT) use was associated with a $2.3 \%$ increase of breast cancer risk (95\% CI, 1.1\%-3.6\%). This effect is reduced after stopping use and is no longer apparent in women who had stopped use for about 5 years or longer, suggesting that HRT may act as a late-stage promoter. In a randomized controlled trial, estrogen plus progestin increased breast cancer risk by $26 \%(95 \% \mathrm{CI}, 1.00-1.59)$; this arm of the trial was stopped due to safety concerns (Rossouw et al., 2002). A recent review further corroborated an increased breast cancer risk in association with current and recent HRT use (95\% CI, 1.21-1.40) (Nelson et al., 2002). The Nurses's Health Study recently reported a synergistic effect of alcohol and HRT on breast cancer risk in postmenopausal women (Chen et al., 2002).

Polycyclic aromatic hydrocarbons. Exposure to polycyclic aromatic hydrocarbons (PAHs) has been hypothesized to increase breast cancer risk, though evidence to date has been inconclusive (Morris \& Seifter, 1992; Ambrosone \& Shields, 1997). PAHs constitute a large class of ubiquitous chemicals that includes many powerful carcinogens (IARC, 1983). Breast tissue is a significant storage depot for lipophilic compounds, including PAHs (Martin et al., 1996; Archibeque-Engle et al., 1997). Normal human mammary cells metabolize PAHs efficiently to reactive intermediates through oxidative activation by Phase I cytochrome P450 enzymes, primarily CYP1A1 and CYP1B1 (Bartley \& Stampfer, 1985; Goth-Goldstein et al., 2003); these reactive intermediates can bind to DNA, causing bulky adducts that can lead to mutations and tumor induction. Using job-exposure matrices, an occupational study found $\mathrm{PAH}$ exposure to be related to increased estrogen receptor positive breast cancer $(\mathrm{OR}=2.27 ; 95 \% \mathrm{CI}$, 1.14-4.54), but not with estrogen receptor negative tumors (Petralia et al., 1999). PAH-DNA adducts have been detected at significantly higher levels in breast tissue of breast cancer patients compared to non-cancer controls (Li et al., 1996; Li et al., 1999; Rundle et al., 2002; Li et al., 2002). Recent results from the Long Island Breast Cancer Study Project supported an association between breast cancer risk and $\mathrm{PAH}-\mathrm{DNA}$ adduct levels in blood $(\mathrm{OR}=1.51 ; 95 \%$ CI, 1.04-2.20) (Gammon et al., 2002). Cigarette smoke contains a number of polycyclic aromatic hydrocarbons, yet no consistent association has been found with breast cancer risk. An opposing anti-estrogenic effect, however, may diminish the appearance of any carcinogenic action of cigarette smoke (MacMahon et al., 1982). Band et al. (2002) attempted to assess the carcinogenic and anti-estrogenic effects of cigarette smoke and found that risk of breast cancer 
was significantly increased in women who had been pregnant and who began smoking within 5 years of menarche $(\mathrm{OR}=1.69 ; 95 \% \mathrm{CI}, 1.13-2.51)$, and nulliparous women who smoked 20 or more cigarettes per day and had smoked for 20 cumulative pack-years or more $(\mathrm{OR}=7.08 ; 95 \%$ CI, 1.63-30.8).

Light-at-night. Exposure to light-at-night has been hypothesized to be related to breast cancer risk through suppression of melatonin levels and subsequent increases in estrogen levels (Stevens et al., 1992; Stevens \& Rea, 2001). In one study, increased breast cancer risk was found among women who ever worked the graveyard shift $(\mathrm{OR}=1.6 ; 95 \% \mathrm{CI}, 1.0-2.5)$ and among women who frequently did not sleep during between 1:00 and 2:00 A.M., the period of the night when nocturnal melatonin levels are typically highest $(\mathrm{OR}=1.14$ per night per week; $95 \% \mathrm{CI}, 1.01$ 1.28) (Davis et al., 2001). In a second study, breast cancer risk was increased in women who worked 30 or more years on the night shift $(\mathrm{RR}=1.36 ; 95 \% \mathrm{CI}, 1.04-1.78)$ (Schernhammer et al., 2001).

\section{COMMUNITY INPUT \& EVALUATION}

Ideas about possible environmental exposures that may be breast cancer risk factors were collected from the community. While the target community was Marin County residents, input received from residents of other communities was accepted. Through this community input process, our intention was to raise awareness about local breast cancer rates, stimulate discussion, and solicit information that could help guide the direction of current and future research. Three methods were used to collect community input. No identifying information was requested from those submitting ideas to the study. Study materials pertaining to the community input are available in a report supplement.

Mail, Email, Telephone. An announcement that described the study and invited community members to submit ideas about possible environmental exposures was circulated in the community through the local newspaper, flyers, community email lists, public service announcements, and the Marin Breast Cancer Watch website. Input was submitted through the mail, telephone, and/or email. Only designated study staff handled community input emails, mail, and phone calls. Once received, community input was stripped of all identifying information and entered into an electronic database. Even though no identifying information was requested, some community members submitted information that was potentially identifying; this information was removed in adherence with the study's protocol to protect confidentiality.

Mapping Workshops. A second announcement invited community members to participate in a public workshop in spring of 2002 to make personal risk perception maps and complete a related questionnaire. This announcement was translated into Spanish and distributed at various locations that provide services to the Spanish speaking community. The idea for the workshops was gleaned from the "Putting Breast Cancer on the Map" project conducted by the Women's Environmental Network in the United Kingdom between April 1997 and June 1999. The workshops that we conducted in Marin County provided interested community members with an opportunity to voice personal concerns about Marin County's breast cancer incidence rates. Workshop participants were led through an exercise that generated a hand-drawn visual representation of her or his personal environment, emphasizing exposures that they thought 
might be relevant to breast cancer. These representations took a variety of forms, including both geographical and chronological. A total of 87 participants submitted questionnaires, and a total of 54 maps were submitted. In some cases, participants worked together to create one map. Two examples of the kinds of map that participants drew are given in Appendix B. Each workshop participant also completed a brief semi-structured self-administered questionnaire about perceived hazards in the environment. Workshops were held in three different locations in Marin County (Point Reyes, San Rafael, Corte Madera). Participants also completed a brief evaluation form to assess the utility of the workshop and offer suggestions for improvement. Workshop participants were given the choice to submit or keep to themselves their questionnaires and/or risk perception maps. When the workshops were completed, each concern from each submitted map was recorded into a database. Responses from the questionnaire also were recorded into a database. Every effort was made to remove potentially identifying information from the database.

Marin County Breast Cancer Study of Adolescent Risk Factors. The third source of community input was a list that summarized the responses to a question from the Marin County Breast Cancer Study of Adolescent Risk Factors (aka, the Adolescent Risk Factor Study or ARFS) dataset. This community research collaboration study was led by Dr. Georgianna Farren at Marin Breast Cancer Watch and Dr. Margaret Wrensch at the University of California at San Francisco, with funding from the California Breast Cancer Research Program. At the end of the questionnaire used in this study was an open-ended question that asked, "Do you have any ideas about what might cause breast cancer?" Responses to this question were transcribed and categorized in a database for consideration by the PERFS research team.

Announcement Distribution. Community members took responsibility for extensive outreach and promotion for the first two methods of community input. Flyers announcing the workshop and requesting community input were distributed to every Marin County employee (approximately 2,000 ) by including a copy of the flyer with each employee's paycheck. This was made possible with the assistance of a Marin County Breast Cancer Research Collaborative partner, the Marin County Department of Health and Human Services. Approximately 2,000 flyers were also distributed or posted at the following locations: grocery stores; medical offices; post offices; libraries; community bulletin boards; schools; small businesses; public bathrooms; retail store dressing rooms; beauty salons; farmers markets; community town meetings; and corporate employees venues. In addition to publicizing the workshops through flyer distribution, community members promoted the invitation for community input by speaking on local radio and community television broadcasts.

Results \& Discussion. Ideas received through mail, email, telephone, workshop maps, and the Adolescent Risk Factor Study formed a bank of nearly 1,500 submitted comments.

Approximately, 336 unique concerns were expressed and were compiled in a list of topics to be considered for current and future research. The research team organized these individual concerns into topical groupings representing the range of concerns of community members who submitted input. Community collaborators created a pictorial display to illustrate the spectrum of categories of environmental concerns (see Figure 1). 


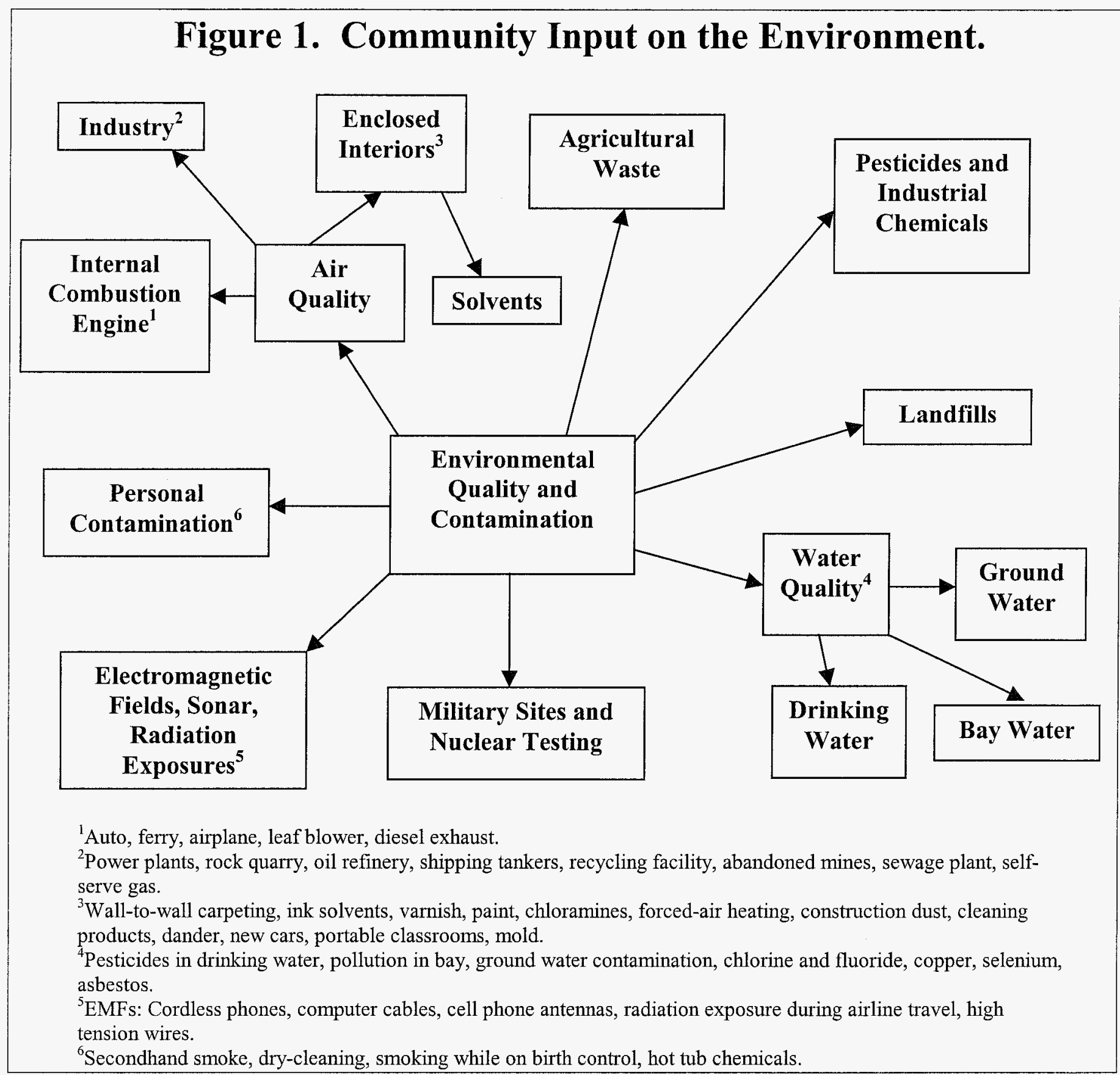


Concerns among the most frequently mentioned were pesticides, water quality, air contamination, and Hamilton Air Force Base. Concerns about water included, but were not limited to chlorine, arsenic, asbestos in pipes, copper, and contamination from degrading cement pipes. Many participants mentioned contamination of air from Richmond oil refineries and vehicle emissions. There were numerous responses calling attention to emissions from a styrofoam factory in Corte Madera. Several hikers noted the use of pesticides on trails. Although the majority of responses were in categories of environmental contamination, also mentioned were concerns such as stress, personal care products, diet, medicines, hormone replacement therapy, and genetics.

The community input findings were supported by a wide variety of solicitation methods. The mapping exercise, workshop questionnaire, email, mail, and telephone responses all indicated a preponderance of concerns about environmental contamination from Hamilton Air Force Base, pesticides, and poor water and air quality. The workshops were successful in increasing community awareness and in stimulating discussion. Workshop facilitators were successful in creating an interesting and comfortable atmosphere for participants.

Evaluation. Table 1 summarizes the responses to the first four questions on the mapping workshop evaluation form.

Table 1. Summary of responses to mapping workshop evaluation form.

\begin{tabular}{lrr}
\hline & No. & $\%$ \\
\hline A. Where did you here about this project?" & 26 & 37 \\
Newspaper & 24 & 34 \\
Flyer & 5 & 7 \\
MBCW Newsletter & 14 & 20 \\
Friend/Acquaintance & 0 & 0 \\
Radio & 12 & 17 \\
Other & & \\
B. Were the questions asked clear and understandable? & 56 & 79 \\
Easy to follow & 9 & 13 \\
Moderate & 3 & 4 \\
Hard to follow & 3 & 4 \\
No response & & \\
C. How easy was it to complete the questionnaire? & 29 & 41 \\
Very easy to complete & 25 & 35 \\
Easy & 10 & 14 \\
Moderate & 2 & 3 \\
Hard & 5 & 7 \\
No response & & \\
D. Was the mapping exercise useful? & 5 & 7 \\
Not at all & 24 & 34 \\
Somewhat useful & 11 & 15 \\
Very useful & 31 & 44 \\
No response & \multicolumn{1}{l}{, } & \\
\hline Multiple responses to question A were possible - therefore percentages exceed & $100 \%$.
\end{tabular}


The last two questions ( $E \& F$ ) on the mapping workshop evaluation form were open-ended. In response to Question E, "Would you like to be more involved in this project? If so, in what way?" only one of the 71 participants was not interested in further involvement; four were not sure; and about 25 indicated how they would like to be more involved in the project (see Box 1). More workshops, surveys, interviews, mapping, and phone work were among the suggestions. A few participants just wanted to be updated or know results. One respondent offered professional services as a support or discussion group facilitator.

Box 1. Ways in which mapping workshop participants indicated that they would like to be more involved in the project.

-More input for study

-Regular check-ups for breast cancer

-However it would be helpful

-Would like to know results, participate in future surveys or follow-up

-Data research

-Want constant updated information

-Glad to participate in any way

-Would like to supply information promoting healthy diet

-Linking more personal cases to background histories and migration

-Understanding of results

-Do door to door mapping

-Could do a street or two in my neighborhood-phone work

-Health education

-Subscribe to newsletter to stay informed

-Interviewing for questionnaires for future mapping, door to door canvassing

-Research

-Set up questionnaires, interview people

-Want information, don't have time to be involved

-I'd like to get involved in educating and advocating for precautionary measures to

eliminate/reduce the exposure to toxics in the environment

-Participate in more workshops of this nature, gather information and share with friends, family, and network word of mouth

-Doing survey work, interviewing, advocacy with elected officials

-Would like to facilitate a support group/discussion group

-The best part is getting people together. This form is too little and not direct enough.

-Would like to see the results

-Would like to know of causes for the cancer rate in Marin

In response to Question F, "Do you have any suggestions for improving this project?" several participants' answers included more workshops, more community input, and more meetings for breast cancer survivors. Responses to this question were more varied (see Box 2). Some participants suggested more mapping to identify "hot zones" or to create a collective communitygenerated map. Many provided positive feedback such as "great," "fantastic," "fun," and "keep doing what you are doing." Others had suggestions about content, such as including more detailed histories, more lifestyle histories, and dietary histories. 
Box 2. Suggestions from the mapping workshop participants for improving the project.

-Get more funding to get more input

-Add questions on lifestyle, smoking, number of children, travel, other areas lived

-Distinguish between time periods in one's life

-Need to map "hot zones" and "clusters " in Marin

-More detailed histories

-Educate people on healthy diet

-Clarify some questions

-Make distinction between most recent house and longest residence

-Why are you giving us toxic smelling SHARPIES? I know they say non-toxic....

-Get more people involved, create questionnaire to facilitate more quantitative data

-Bring outline maps for everyone to add to

-Keep on meeting regularly and sharing our research

-Good if community involved has more input in design and on output of study. We could all

be more powerful in organizing.

-Press releases to all media.

-Call all survivors together

-Give a survey

-Don't really understand the project, hope this survey helps

-If you have breast cancer, date of diagnosis. Many more questions. How long in location when diagnosed?

-Confused about environmental emphasis and other life factors like smoke, birth control pills, etc.

-Fine tune questionnaire, make it more efficient for it to be completed in less time, more organized.

-Post on your website resources women can use to limit their exposure to toxics- books, websites, and organizations.

-More community workshops like this one to inform the public. Thank you.

-Ask a few more detailed questions on diet throughout years of one's life. Perhaps foods we grew up on are not what we eat now or perhaps they have changed and are more or less toxic. -Please keep discussion to a minimum. Stay on task. Organize discussion groups or support groups for people to air their feelings rather than in this situation where we're volunteering our time to provide data.

-Put out a call via newspapers and radio to have all breast cancer persons who wish to come to a Saturday meeting. Have questionnaire with good specifics- pins - big map.

-I think that it would help to have some initial discussion about contaminants in order to spark thought. I know that I'll remember more later, especially after talking to family and friends. I know that you don't want to influence us, but perhaps it could be led by the community members themselves. Or could we create a collective map together. It would be more collaborative.

-Expand project to all endocrine cancers

-Awareness is key aspect and getting people involved at the grassroots level is essential. It is up to this type of effort to continue to put pressure on those responsible for the health and safety of women in Marin County.

-Use the knowledge of clergymen/women as well as natural healers. Holistic Life Festival has lots to offer. Have a booth at New Age Expo. 


\section{QUESTIONNAIRE DEVELOPMENT \& EVALUATION}

Questionnaire Development. Questionnaire items from completed and ongoing breast cancer studies were reviewed. Table 2 lists the questionnaires that were reviewed. Questions pertaining to known risk factors and environmental exposures from the Adolescent Risk Factor Study (ARFS) were retained for the PERFS pilot study questionnaire.

Table 2. Study questionnaires that were reviewed while developing our questionnaire.

\begin{tabular}{|c|c|c|}
\hline Study/Project & $\begin{array}{c}\text { Principal } \\
\text { Investigator }\end{array}$ & Year* \\
\hline Marin County Breast Cancer Study of Adolescent Risk Factors & Wrensch / Farren & 2001 \\
\hline Breast Cancer Detection Demonstration Project & C. Shairer & 1998 \\
\hline Women's Health Study & L. Brinton & 1996 \\
\hline Women's Interview Study of Health & L. Brinton & 1993 \\
\hline Breast Cancer and the Environment on Long Island & M. Gammon & 1997 \\
\hline Breast Cancer Comprehensive Project & $\mathrm{NAPBC} * *$ & 1998 \\
\hline Newton Breast Cancer Study & J. Brody & 1997 \\
\hline Cape Cod Women's Health Study & J. Brody & 1999 \\
\hline California Teachers Study $(1995-1996,1997,2000)$ & R. Ross & various \\
\hline Bay Area Women's Health Study & E. John & 2000 \\
\hline Indoor Environmental Quality Survey & USEPA $^{* * *}$ & 1998 \\
\hline National Human Exposure Assessment Survey ('95, '97, '98) & $\mathrm{USEPA}^{* * *}$ & various \\
\hline Electric Power and the Risk of Breast Cancer & Stevens / Davis & 1993 \\
\hline
\end{tabular}

*Pertains to last year of data collection or publication date.

**National Action Plan on Breast Cancer

****United States Environmental Protection Agency

In addition to standard risk factor data, the questionnaire for the PERFS pilot study collected data about aspects of the personal environment within 10 years of breast cancer onset for cases and the 10 years prior to the case ascertainment period for controls. Previously used questions were used whenever possible for other topics. To summarize, the PERFS questionnaire has 12 sections: (I) General background and maternal history; (II) Detailed residential, school, and work history for the 10 years prior to diagnosis for cases and interview for controls, lifetime Marin County residence, school and workplace history, lifetime years and highest level of schooling, and residential PAH sources; (III) Exposure history section collects detailed exposure information for the 10 years prior to diagnosis for cases and interview for controls, including hobbies, arts and crafts, PAH inhalation exposures, pesticides, and other exposures, such as chlorine sources and dry cleaning; (IV) Alcohol and tobacco includes assessment of lifetime use as well as specific frequencies and types for the proximate 10 years and secondhand smoke exposures; (V) Dietary PAH exposures in proximate 10 years, including cooking methods likely to involve exposures to PAHs; (VI) Family and social life experiences, changes, and activities for 10 years proximate related to family and social support and acceptance, isolation, selfconfidence, friendships, trust, and sexual activity; (VII) Major life events in the proximate 10 year period based on the Holmes and Rahe scale (Holmes \& Rahe, 1967); (VIII) Exercise in adolescence and the proximate 10 years based on physical activity questions from the California Teachers Study; (IX) Demographic and socioeconomic factors, including highest education, marital status, family's contemporary socioeconomic status and that prior to age 21 , household 
annual income; (X) Menstruation and body development section includes the ages periods started, height and weight at various times; (XI) Health history includes a variety of standard breast cancer risk factors and other possibly important factors (i.e., detailed reproductive and breast feeding history, family history of breast cancer, menopausal status, lifetime use of birth control pills or hormone replacement therapy use, prior non-breast cancers, screening practices, breast procedures, radiation treatments, body weight and pre-diagnosis body mass index, how breast cancer first detected for cases); and (XII) Participant's ideas about causes of breast cancer in order to assess which study variables are commonly considered by the participants to be causes of breast cancer.

Pilot Testing of PERFS Questionnaires. Informal pilot testing was conducted with approximately 20 volunteer Marin County women recruited through $\mathrm{MBCW}$ to resolve any major problems with the content and flow of the questionnaire and to estimate the length of time needed to complete the interview. The participants in the informal pilot test completed a draft version of the study questionnaire and submitted suggestions for its improvement. The completed questionnaires from the informal pilot test were destroyed after incorporating the participants' suggestions. Formal pilot testing was conducted with 20 cases identified through the Northem California Cancer Center and 21 controls recruited by random digit dialing. Summary demographics of the formal pilot test participants appear in Table 3.

Table 3. Summary demographics of formal pilot test participants.

\begin{tabular}{|c|c|c|c|c|}
\hline & \multicolumn{2}{|c|}{$\begin{array}{c}\text { Cases } \\
(\mathrm{n}=20)\end{array}$} & \multicolumn{2}{|c|}{$\begin{array}{l}\text { Controls } \\
(\mathrm{n}=21)\end{array}$} \\
\hline & No. & $\%$ & No. & $\%$ \\
\hline \multicolumn{5}{|l|}{ Age } \\
\hline$\leq 50$ & 12 & 60 & 11 & 52 \\
\hline$>50$ & 8 & 40 & 10 & 48 \\
\hline \multicolumn{5}{|l|}{ Race/ethnicity } \\
\hline White & 17 & 85 & 21 & 100 \\
\hline Other & 3 & 15 & 0 & 0 \\
\hline \multicolumn{5}{|l|}{ Education } \\
\hline$<$ Bachelor degree & 5 & 25 & 9 & 43 \\
\hline$\geq$ Bachelor degree & 15 & 75 & 12 & 57 \\
\hline \multicolumn{5}{|c|}{ Socioeconomic Status (before age 21) } \\
\hline Middle or lower & 16 & 80 & 17 & 85 \\
\hline Upper middle/Upper & 4 & 20 & 3 & 15 \\
\hline \multicolumn{5}{|c|}{ Socioeconomic Status (current) } \\
\hline Middle or lower & 10 & 50 & 13 & 62 \\
\hline Upper middle/Upper & 10 & 50 & 8 & 38 \\
\hline
\end{tabular}

Interviews could take place at the participant's home, the MBCW office, or anywhere that was convenient for the participant. After their interviews, the pilot participants were asked to complete a brief survey to evaluate the questionnaire. Women who agreed to participate in the questionnaire portion of the study were given the option to contribute a buccal cell and/or nipple aspirate fluid (NAF) sample. The buccal cell and NAF samples were collected by the interviewer at the same location where the interview took place; neither procedure requires a 
special setting. Collection of these biospecimens is described further below. A $\$ 50$ check was offered to each participant in the formal pilot test.

Data from most of the questionnaire variables were entered into a database. Summary statistics and examples of responses for selected variables are presented below in Tables 4 and 5; Boxes 3 and 4. Given the small number of participants, no formal significance tests or multivariate analyses were conducted to adjust for age or other factors. Rather, these summaries provide a brief description of our participants and some crude prevalence estimates that could be used in sample size and power calculations.

Table 4. Percent of PERFS pilot study participants who in the past 10 years (prior to diagnosis for cases) were ever exposed to various activities or exposures.

\begin{tabular}{lr}
\hline Exposure & $\%$ \\
\hline Used outdoor grill or barbecue & 55 \\
Used indoor grill or barbecue & 0 \\
Burned candles indoors & 95 \\
Burned incense indoors & 18 \\
Burned kerosene indoors & 14 \\
Used insect repellent on own skin or clothes & 68 \\
Applied lice control product on skin, hair, clothing of self or someone else & 27 \\
Were in a public place when insects or plants were sprayed & 14 \\
Used pesticides or chemicals to control fleas or ticks & 55 \\
Used pesticides or chemicals to control termites & 23 \\
Lived or worked on farm or ranch where pesticides were used & 0 \\
Left home for a few hours because it was being fumigated & 27 \\
Saw a fogger truck or cropduster spray in your neighborhood & 9 \\
Employed professional lawn care service & 32 \\
Swam in chlorinated swimming pool & 86 \\
Used hot tub & 72 \\
Played golf & 36 \\
Had clothing dry-cleaned & 86 \\
Regularly used car & 100 \\
Regularly used bus & 18 \\
Regularly spent time engaged in physical activity near road with cars & 82 \\
Change oil & 5 \\
Used air conditioning in house & 36 \\
Chlorine bleach used in house & 100 \\
Mold or mildew products other than chlorine bleach used in house & 50 \\
\hline
\end{tabular}

Box 3. Other regular sources of exposure to burning organic material listed by participants.

-lawn mowing

-used gas as a gardener

-wood burning camp fires - 2 weeks/year

-campfires -2 times/year

-wood stove/fireplace - burned wood, paper, cardboard 
Table 5. Percent of PERFS pilot study participants who in the past 10 years (prior to diagnosis for cases) ever participated for a total of 6 months or longer in work or a hobby that involved various exposures.

\begin{tabular}{lr}
\hline Exposure & \% \\
\hline Epoxies, caulks, silicone glues & 23 \\
Soldering & 0 \\
Photography development & 9 \\
Oil painting & 5 \\
Woodworking or refinishing furniture & 0 \\
Ceramics or pottery making & 0 \\
Leather crafting & 0 \\
Printer's inks & 9 \\
Cotton or other textile fibers or dust & 14 \\
Welding fumes & 0 \\
Other activities involving fumes, smoke, gas, or vapors & 5 \\
\hline
\end{tabular}

Box 4. Other activities involving fumes, smoke, gas, or vapors listed by participants. -Turpentines, solvents - oil painting.

-Plastic bags to contain kits.

Evaluation. Tables 6 and 7 along with Boxes 5 and 6 summarize feedback from the questionnaire pilot participants. Many evaluation forms were returned incomplete, indicating the need to highlight the importance of completing evaluation forms.

Table 6. Summary of responses to questionnaire evaluation form.

\begin{tabular}{lrr}
\hline & No. & $\%$ \\
\hline 1. Were the questions asked clear and understandable? & 37 & 90 \\
Clear and easy to understand & 3 & 7 \\
Moderately clear and mostly easy to understand & 0 & 0 \\
Unclear and difficult to understand & 1 & 3 \\
No response & 31 & 76 \\
2. How easy was it to complete the interview? & 6 & 15 \\
Very easy to complete & 2 & 5 \\
Easy & 1 & 2 \\
Moderate & 1 & 2 \\
Difficult & 1 \\
No response & 2 \\
3. Were there questions that you think should be removed from our survey? & 38 \\
Yes* & 2 & 5 \\
No & 5 \\
No response & 8 \\
4. Are there questions that you think should be added to our survey? & 20 \\
Yes & 28 \\
No & 68 \\
No response & 5 \\
\hline
\end{tabular}

$*$ One participant suggested removing the question regarding family income. 
Box 5. List of topics that participants suggested adding to the questionnaire.

-Environmental questions.

-Life style questions.

-Household cleaning products - i.e., Windex, etc.

-Childhood environments.

-Diet. Food chemicals.

-Past family members' history of breast cancer - grandmothers, etc.

-Exercise.

-Trauma in earlier years.

-Lots more.

Box 6. Responses to the question, "Do you have any other suggestions for improving this questionnaire?"

-Give participants more advanced knowledge of what questions would be about. For example, it was difficult to impossible to remember such things as the \# times various pesticides were used. -Requested too much detail for things insignificant.

-Ask subject to write down other information in advance, as you did for employment and residence information (e.g., dates of surgery, medications, etc.)

-Other close relatives who've had breast cancer.

-Suggest trying to get accurate dates.

Table 7. Evaluation of willingness to provide various biologic samples and suggested compensation.

\begin{tabular}{lrrrrr} 
& \multicolumn{4}{c}{ \% Willing $^{*}$} & \multicolumn{3}{c}{ Suggested Compensation } \\
Sample Type & to Provide $^{*}$ & Mean & Min. & Max. & No. \\
\hline 1 tube of blood $(\sim 2$ tsp. $)$ & 51 & $\$ 15$. & $\$ 0$. & $\$ 50$. & 9 \\
3 tubes of blood $(\sim 6$ tsp. $)$ & 41 & $\$ 18$. & $\$ 0$. & $\$ 50$. & 7 \\
5 tubes of blood $(\sim 1 / 4$ cup) & 34 & $\$ 29$. & $\$ 0$. & $\$ 100$. & 7 \\
Urine sample & 85 & $\$ 18$. & $\$ 0$. & $\$ 100$. & 18 \\
Cheek cell sample & 80 & $\$ 17$. & $\$ 0$. & $\$ 100$. & 17 \\
Fat sample, punch biopsy-buttocks & 32 & $\$ 37$. & $\$ 0$. & $\$ 100$. & 7 \\
Fat sample, punch biopsy-breast & 27 & $\$ 62$. & $\$ 0$. & $\$ 200$. & 5 \\
\hline
\end{tabular}

"Many left the evaluation form incomplete, thus the percentage indicating whether they were willing to donate a certain sample type may be an underestimate.

\section{BUCCAL CELL COLLECTION}

Each respondent was asked to consent to giving three buccal cell samples by swabbing the inside of her cheeks with small, sterile brushes (only one respondent did not consent). Each brush was placed into a small, $1.5 \mathrm{~mL}$ plastic centrifuge tube with $1 \mathrm{~mL}$ of $50 \mathrm{mM} \mathrm{NaOH}$ and labeled with the participant's identification number, interviewer, and date of interview. The tubes were mailed to a molecular epidemiology laboratory at the University of California at San Francisco for future genetic analyses. 


\section{NIPPLE ASPIRATE FLUID COLLECTION \& EVALUATION}

Background. Nipple aspiration is a non-invasive means of collecting breast tissue. Expression of genes involved in the metabolism of various exogenous compounds were analyzed in the nipple aspirate fluid (NAF) samples. The results from the NAF analysis appears in the Nipple Aspirate Fluid Analysis section below.

Nipple Aspirate Fluid Collection. The study interviewers underwent a training session with Dr. Nicholas Petrakis of the University of California at San Francisco. Dr. Petrakis has extensive experience with the nipple aspirate procedure and research involving NAF samples. The training included studying a videotape which documented the procedure, observing a live demonstration of the procedure, and practicing the procedure under the guidance of Dr. Petrakis. About half way through the study, a second training session was conducted with Dawanda Pesicka, P.A., who has extensive experience with the NAF collection procedure and has worked closely with Dr. Susan Love.

The NAF collection procedure is a non-invasive procedure that consists of placing a small cup, which is attached to a syringe, over the nipple. The syringe is then pulled out to exert negative pressure. If fluid appeared on the nipple, it was collected in small capillary tubes. Each capillary tube was placed into a screw-top glass centrifuge tube labeled with the participant's identification number and breast side (i.e., left or right). Interviewers took care to avoid potential contamination of the samples by swabbing the nipples with alcohol prior to attempting aspiration and also by immersing their gloved fingers into alcohol prior to touching any area where fluid may be expected to appear.

Women who participated in the NAF collection component of the study were asked to complete a brief evaluation form comparing the NAF procedure with other procedures or activities, such as mammography, pap smear, and dental work. The collected specimens were immediately placed in a Styrofoam container with dry ice and transported as soon as possible (usually within 12 hours, but not longer than 48 hours after collection) to the $-70^{\circ} \mathrm{C}$ freezer at the county Health Department office in San Rafael for subsequent transfer to Lawrence Berkeley National Laboratory.

Evaluation. Tables 8 and 9 summarize the evaluations of the NAF procedure by participants using two different ranking methods. Table 8 gives the mean, standard deviation, minimum, and maximum ratings for each procedure/activity. For Table 9, a ratio of each procedure/activity rating to the NAF rating was calculated for each participant. Then, the mean of these ratios was calculated for each procedure/activity. For example, on average, the participants found that slamming one's hand in a car door to be many times more uncomfortable than the NAF procedure. Getting a hair cut or having a blood pressure measurement taken were found to be more comfortable relative to the NAF procedure. Using either analysis method, the NAF procedure appears to be comparable in comfort rating to other medical/health procedures such as dental cleaning and pap smear. 
Table 8. Summary statistics of rating of various procedures or activities on a scale from 1 to $10(1=$ Not at all uncomfortable; $10=$ Extremely uncomfortable $)$.

\begin{tabular}{lrrrr}
\hline Procedure/Activity & Mean & SD & Min. & Max. \\
\hline Hair cut & 1.2 & 0.6 & 1 & 4 \\
Blood pressure measurement & 1.7 & 1.0 & 1 & 6 \\
Dental cleaning & 3.2 & 1.8 & 1 & 8 \\
Nipple aspiration & 3.2 & 1.4 & 1 & 7 \\
Pap smear & 3.5 & 2.0 & 1 & 10 \\
Blood draw & 3.9 & 1.9 & 1 & 10 \\
Injection/shot & 3.9 & 2.0 & 1 & 10 \\
Mammogram & 4.4 & 2.1 & 2 & 10 \\
Dental drilling & 6.0 & 2.3 & 2 & 10 \\
Hitting thumb with a hammer & 8.8 & 1.5 & 4 & 10 \\
Slamming hand in a car door & 9.2 & 1.2 & 5 & 10 \\
\hline
\end{tabular}

Table 9. Mean ratio of rating of various procedures or activities to NAF comfort rating.

\begin{tabular}{lr}
\hline Procedure/Activity & Mean \\
\hline Slamming hand in a car door & 3.4 \\
Hitting thumb with a hammer & 3.3 \\
Dental drilling & 2.2 \\
Mammogram & 1.5 \\
Blood draw & 1.5 \\
Injection/shot & 1.5 \\
Pap smear & 1.3 \\
Dental cleaning & 1.2 \\
Nipple aspiration & 1.0 \\
Blood pressure measurement & 0.6 \\
Hair cut & 0.4 \\
\hline
\end{tabular}

\section{NIPPLE ASPIRATE FLUID ANALYSIS}

Originally, we intended to evaluate the feasibility of measuring both CYP1A1 and CYP1B1 gene expression in nipple aspirate fluid (NAF). The method that we were using at the time that the proposal was submitted allowed the simultaneous measurement of both CYP1A1 and CYP1B1. Because the NAF specimens are very small (less than 100 cells), we developed a more sensitive method. With the more sensitive method, however, it was no longer possible to simultaneously measure both $C Y P 1 A 1$ and $C Y P 1 B 1$. Since recently completed work suggested that $C Y P I B 1$ may play a more important role than $C Y P 1 A 1$ in modifying the impacts of environmental exposures on breast cancer risk (Goth-Goldstein et al., 2003), we decided to attempt to measure CYP1B1 for this pilot study.

Specimens. Nipple aspirate fluid (NAF) specimens were delivered to Lawrence Berkeley National Laboratory on dry ice and stored at $-80^{\circ} \mathrm{C}$ until analysis. A total of 23 individuals donated nipple aspirate fluid. The specimens are described in Table 10. NAF specimens from 
11 individuals were used for gene expression analysis while 12 were preserved for future pesticide analysis.

Table 10. Summary description of NAF specimens used in mRNA analyses. Volume is total volume of NAF obtained from both breasts.

\begin{tabular}{ccr}
\hline $\begin{array}{c}\text { Specimen } \\
\text { Dummy Id }\end{array}$ & $\begin{array}{c}\text { Age } \\
\text { (years) }\end{array}$ & $\begin{array}{c}\text { Volume } \\
(\mu \mathrm{L})\end{array}$ \\
\hline 1 & 71 & 20 \\
2 & 55 & 120 \\
3 & 41 & 70 \\
4 & 43 & 25 \\
5 & 55 & 30 \\
6 & 57 & 70 \\
7 & 51 & 50 \\
8 & 53 & 10 \\
9 & 40 & 15 \\
10 & 29 & 10 \\
11 & 28 & 10 \\
\hline
\end{tabular}

RNA Isolation. Total RNA was isolated from NAF specimens using TRI Reagent as recommended by the manufacturer (Chomczynski et al., 1987; TRI reagent, 1995). Several changes were made to improve the yield of isolated RNA. First, a carrier was added to the precipitation step ( $20 \mu \mathrm{g}$ glycogen), and the centrifugal force of the precipitation step was increased from 14,000 rcf to 18,000 rcf. The resulting RNA was protected from degradation by the immediate addition of 20 units of a thermally-stable rnase inhibitor. The entire sample was used in the reverse transcription reaction.

Reverse Transcription. RNA from each NAF specimen was reverse transcribed to cDNA at $42^{\circ} \mathrm{C}$ for 1 hour using $0.5 \mu \mathrm{g}$ oligo (dT) 16 and 200 units of RnaseH-minus variant of Moloney murine-leukemia virus reverse transcriptase. The resulting cDNA was stored at $-20^{\circ} \mathrm{C}$ or amplified immediately.

Measuring gene expression levels. The expression levels of three genes: keratin-18, $\beta$-actin, and CYPIB1, were measured using a recently developed PCR assay for calibrator-normalized relative quantitation (Goth-Goldstein et al., 2003, Goth-Goldstein \& Russell, 2002). The cDNA isolated from each NAF specimen was amplified three times, simultaneously, but in separate reactions with $\beta$-actin primers (Horikoshi et al., 1992), CYP1B1 primers (Larsen et al., 1998; Keshava et al., 2002), or keratin-18 primers (Latil et al., 2001). All primer sets are designed to span an intron, thus excluding amplification of any contaminating genomic DNA. With the exception of the "Pooled" specimen (see Table 11), specimens were amplified using a microcapillary thermal cycler with real-time product detection by fluorescence (LightCycler, Roche Molecular Biochemicals). The "Pooled" specimen was amplified using an ABI Prism 7900 detection system. A calibrator was obtained by isolating RNA from primary cultures of a human mammary epithelial cell line (HMEC184). The cDNA from the calibrator and a negative control were included in each PCR analysis of the NAF specimens. 
Results. In NAF specimens from 11 individuals (representing 5 separate tests), CYPIBI gene expression level could not be detected. However, gene expression of constitutively expressed genes, such as $\beta$-actin or keratin-18, could be detected in most of the NAF specimens (see Table 11). No relative quantitation of gene expression could be made; instead, signal intensity is rated from the weakest $(+)$ to the strongest $(+++++)$ for each gene measured. The signal intensity was based on the cycle number where the fluorescent signal first increased above background as determined by the LightCycler software.

Table 11. Qualitative assessment of NAF gene expression. Signal intensity is rated from weakest $(+)$ to strongest $(+++++)$.

\begin{tabular}{l|c|c|ccc}
\hline \multicolumn{1}{c|}{ Specimen } & No. of & Specimen & \multicolumn{3}{|c}{ Gene Expression Results } \\
Dummy ID & Capillary Tubes & Volume $(\mu L)$ & CYPIBI & $\beta$-actin & keratin-18 \\
\hline $4(\mathrm{~L})$ & 1 & 40 & nd & nd & + \\
$5(\mathrm{~L}, \mathrm{R})$ & 2 & 40 & nd & nd & + \\
$6(\mathrm{~L}, \mathrm{R})$ & 2 & 70 & nd & nd & + \\
$2(\mathrm{~L}, \mathrm{R})$ & 4 & 120 & $\mathrm{nd}$ & ++ & +++ \\
$*$ Pooled & 12 & 200 & nd & nd & $\mathrm{nd}$ \\
†calibrator & na & na & ++++ & +++++ & ++++ \\
\hline
\end{tabular}

*The pooled NAF specimen represents 8 individuals.

${ }^{\dagger}$ nd indicates signal not detected.

${ }^{\ddagger} \mathrm{RNA}$ isolated from HMEC 184 cells were used as a calibrator.

To increase sensitivity, the amount of NAF used in each successive test was increased, but even after pooling NAF from eight individuals (about $200 \mu \mathrm{L} \mathrm{NAF),} \mathrm{no} \mathrm{CYPIBI} \mathrm{gene} \mathrm{expression}$ measurement could be made. Normally, CYPIBI levels are expressed as a ratio to a reference gene, $\beta$-actin. This corrects for sample variations in the amount and quality of the isolated RNA. The ratio of $C Y P 1 B 1: \beta$-actin for the sample is divided by the CYP1B1: $\beta$-actin ratio for the calibrator (HMEC 184) in order to correct for run-to-run variations and, most importantly, differing amplification efficiencies between the two primer sets. The reliability of the assay to measure CYP1B1 expression was determined previously to have a variance of $12 \%$ (GothGoldstein et al., 2003).

The identity and purity of PCR products were evaluated following the amplification by a melting curve analysis. The melting curve is unique to each product and is dependent on the length and sequence of the PCR product. Figure 2 shows the melting curve analysis of CYPIB 1 products formed during the analysis of NAF specimens $\# 2$ and $\# 4$. Specific product is formed at $90^{\circ} \mathrm{C}$ as shown by the known calibrator sample HMEC 184; however, the NAF specimen formed only non-specific products represented by a melting peak at $82^{\circ} \mathrm{C}$ and is negative for $C Y P I B I$ specific product. Figure 3 shows the positive confirmation of keratin-18 product for NAF specimen $\# 4$ at $86^{\circ} \mathrm{C}$

Discussion. During real-time reverse transcription-coupled polymerase chain reaction (RTPCR), specimens are heated and cooled repeatedly in order to amplify a specific gene target. An exponential accumulation of gene target (or PCR product) is measured after each cycle by detecting a fluorescence signal. The concentration of an unknown sample is determined from the first cycle $(\mathrm{Ct})$ of the PCR assay in which the fluorescent signal can be distinguished from the 

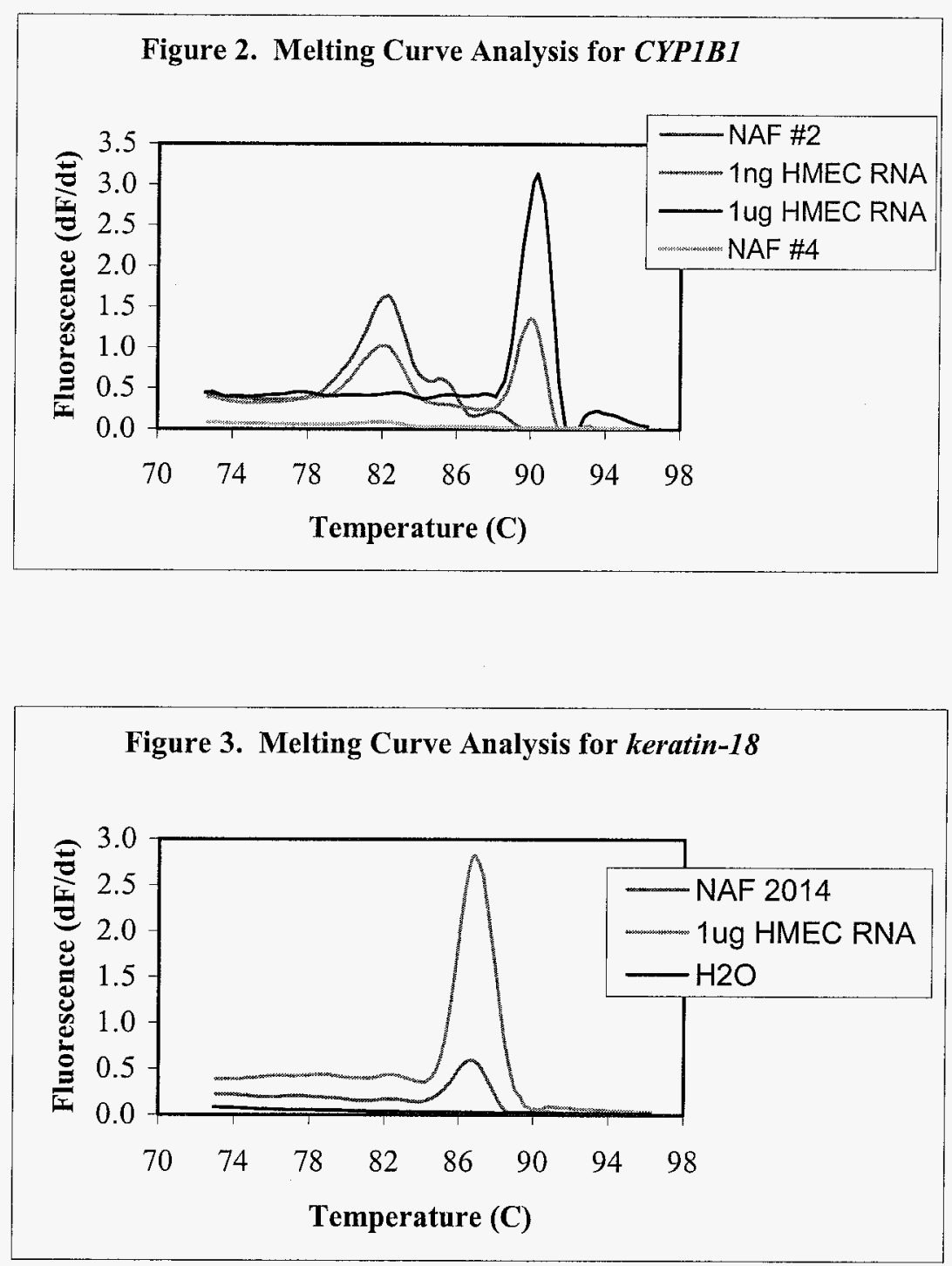

background noise or threshold of the reaction mixture (see Figure 4). For example, the expression level of keratin-18 in NAF specimen \#2 was compared to $1 \mu \mathrm{g}$ and $1 \mathrm{ng}$ of the calibrator (HMEC 184) in Figure 4. Threshold cycles (Ct) of 34.7, 16.1, and 33.8 were measured, respectively. Since 1ng of RNA isolated from the HMEC 184 cell line represents approximately 100 cells, we can estimate the number of cells contained in NAF specimen $\# 2$ to be slightly less than 100 cultured epithelial cells. This observation agrees with previously published data on the average yield of epithelial cells in NAF ( 120 cells) (Dooley et al., 2001). The small volume of NAF specimen precluded any independent measurement of cell number of RNA yield. The keratin-18 gene was included in the analysis of the NAF specimen as a marker of epithelial cell content. An analysis of $\beta$-actin levels was included to measure the total number of cells collected.

Only NAF specimen $\# 2$ contained enough cells to produce clear keratin- 18 and $\beta$-actin signals. The remaining specimens either did not contain enough cells or were degraded during the 
Figure 4. Real-time RT-PCR of keratin-18

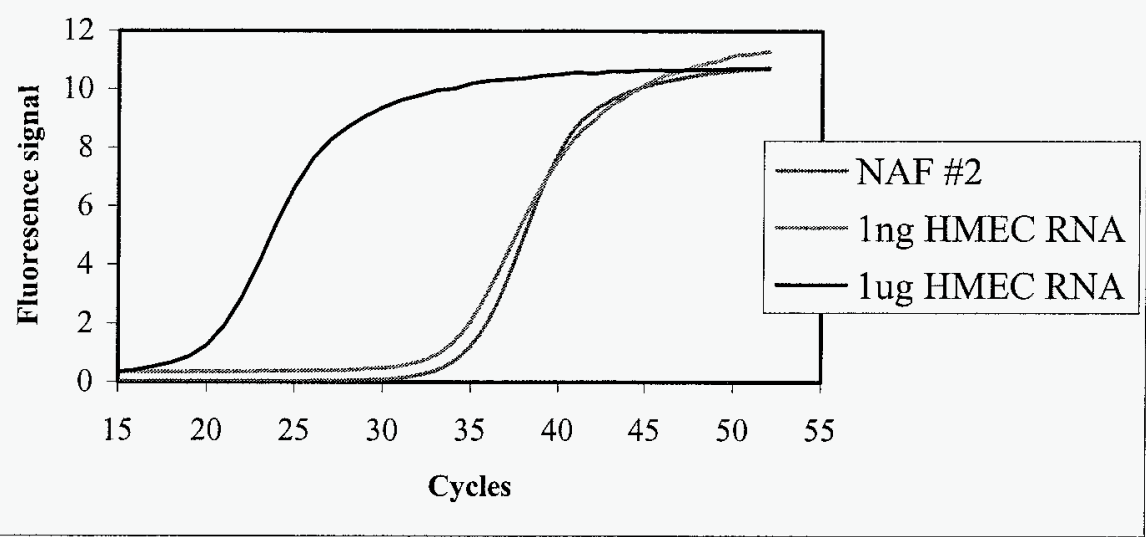

handling and isolation process. There was a large variability in the amount and apparent quality of NAF specimen. For example, NAF specimen \#6 contained a higher than average volume of fluid $(70 \mu \mathrm{L})$ and was expected to yield a stronger keratin-18 signal. The specimen appeared dark brown and contained a large amount of insoluble material, possibly cell debris. This could indicate that the specimen had degraded. If our estimate of cell count is accurate, we would need to collect 5-fold to 10-fold more cells in order to accurately and reproducibly measure transiently expressed genes (like CYP1B1).

\section{DISCUSSION}

This pilot study was a collaborative project that included academic researchers and Marin County community members, as well as hired administrative, research staff and interviewers.

The project aims were clearly defined and achieved, and the project timeline was met. There were many accomplishments during the course of the year: a questionnaire was developed; the NAF collection protocol was amended several times to improve successful collection within a field setting; community mapping workshops were conducted with an enthusiastic community group; community input was summarized; interviews were conducted to pilot test the questionnaire; NAF specimens were analyzed; articles were located and ideas shared; hypotheses for future studies were developed.

In this process, a few areas of difficulty were identified that are briefly discussed below.

1. Budget: The project was not adequately budgeted. Collection and consideration of community ideas, researching hypotheses, and reviewing other questionnaires all took more time than anticipated. The NAF collection required more training time and more interviewer time than originally budgeted.

2. NAF Collection: The NAF collection took more time and more participants than originally anticipated. The NAF collection also was frustrating for the interviewers. The 
success rates initially were low, and they found the procedure in the home less comfortable than if it were conducted in a clinical setting as variables such as privacy, cold temperatures, and distractions were difficult to control. The intimacy of the contact occasionally placed strain on comfort of the interviewers. The fact that mRNA was going to be analyzed placed some restrictions on methods used to obtain the fluid.

3. Refining the Study Topics: Practical limitations of a case-control epidemiologic study on the scope and breadth of topics created a lengthy dialogue and learning experience for both the community members and the researchers. The community collaborators represented numerous community concerns that they initially desired to further investigate. The process of the literature review, the difficulty of obtaining accurate information on some topics through a questionnaire, and the need to establish plausible and testable hypotheses all contributed to a time consuming and cumbersome experience and the elimination of some topics of interest from this particular study.

4. Several of the community members on the research team had initially envisioned a dialogue with the broader community (beginning with the mapping workshops) that was beyond the scope of the project. The limitations placed on this potential dialogue by time constraints, financial considerations, and confidentiality requirements were a source of frustration for some of the community collaborators.

5. Future Use of Study Data: Each type of entity (e.g., community collaborator or academic researcher) brings different perspectives and long-range goals to this type of project. There has been discussion regarding future availability of the questionnaire and of deidentified quantitative and qualitative information obtained in this pilot study. Ethical standards and regulations concerning research that involves human participants define the scope of appropriate research data use.

\section{REFERENCES}

Ambrosone CB, Shields PG. Molecular epidemiology of breast cancer. Prog Clin Biol Res 1997,396:83-99.

Ames BN. Dietary carcinogens and anticarcinogens. Oxygen radicals and degenerative diseases. Science 1983,221:1256-1264.

Archibeque-Engle SL, Tessari JD, Winn DT, Keefe TJ, Nett TM, Zheng T. Comparison of organochlorine pesticide and polychlorinated biphenyl residues in human breast adipose tissue and serum. J Toxicol Environ Health 1997,52:285-293.

Band PR, Le ND, Fang R, Deschamps M. Carcinogenic and endocrine disrupting effects of cigarette smoke and risk of breast cancer. Lancet 2002,360:1044-1049. 


\section{REFERENCES, continued}

Bartley JC, Stampfer MR. Factors influencing benzo[a]pyrene metabolism in human mammary epithelial cells in culture. Carcinogenesis 1985,6:1017-1022.

Bernstein L, Henderson BE, Hanisch R, Sullivan-Halley J, Ross RK. Physical exercise and reduced risk of breast cancer in young women. J Natl Cancer Inst 1994,86:1403-1408.

Chen WY, Colditz GA, Rosner B, et al. Use of postmenopausal hormones, alcohol, and risk for invasive breast cancer. Ann Intern Med 2002,137:798-804.

Chomczynski P et. al. (1987) Single step method of RNA isolation by acid guanidinium thiocyanate-phenol chloroform extraction. Anal. Biochem.162:156-159.

Collaborative Group on Hormonal Factors in Breast Cancer. Breast cancer and hormonal contraceptives: collaborative reanalysis of individual data on 53297 women with breast cancer and 100239 women without breast cancer from 54 epidemiological studies. Lancet 1996,347:1713-1727.

Collaborative Group on Hormonal Factors in Breast Cancer. Breast cancer and hormone replacement therapy: collaborative reanalysis of data from 51 epidemiological studies of 52,705 women with breast cancer and 108,411 women without breast cancer. Lancet 1997,350:10471059.

Davis S, Mirick DK, Stevens RG. Night shift work, light at night, and risk of breast cancer. J Natl Cancer Inst 2001,93:1557-1562.

Dooley WC et al. (2001) Ductal Lavage for Detection of Cellular Atypia in Women at High Risk for Breast Cancer. JNCI. 93:1624-1632.

Gammon MD, John EM, Britton JA. Recreational and occupational physical activities and risk of breast cancer. J Natl Cancer Inst 1998,90:100-117.

Gammon MD, Santella RM, Neugut AI, et al. Environmental toxins and breast cancer on long island. I. Polycyclic aromatic hydrocarbon DNA adducts. Cancer Epidemiol Biomarkers Prev 2002,11:677-685.

Giovannucci E, Stampfer MJ, Colditz GA, et al. Recall and selection bias in reporting past alcohol consumption among breast cancer cases. Cancer Causes Control 1993,4:441-448.

Goth-Goldstein R, Erdmann CA, Russell M. Cytochrome P4501B1 expression in normal breast tissue. Polycyclic Aromatic Compounds 2003 (In press).

Goth-Goldstein R, Russell M. (2002) Oxidative damage, CYP1B1 and Breast Cancer. U.S. Army Medical Research and Materiel Command Final Report, DAMD17-01-1-0543. 


\section{REFERENCES, continued}

Hamajima N, Hirose K, Tajima K, et al. Alcohol, tobacco and breast cancer--collaborative reanalysis of individual data from 53 epidemiological studies, including 58,515 women with breast cancer and 95,067 women without the disease. Br J Cancer 2002,87:1234-1245.

Hankinson SE, Hunter DJ. Breast Cancer. In: Textbook of Cancer Epidemiology. Edited by Adami HO, Hunter DJ, Trichopoulos D. New York: Oxford University Press; 2002.

Harvey EB, Schairer C, Brinton LA, Hoover RN, Fraumeni JF, Jr. Alcohol consumption and breast cancer. J Natl Cancer Inst 1987,78:657-661.

Holmes TH, Rahe RH. The Social Readjustment Rating Scale. J Psychosom Res 1967,11:213218.

Horikoshi T, Danenberg K, Stadlbauer T, Volkenandt M, Luke C S, Aigner K, Gustavsson B, Leichman L, Froesing R, Ray M, Gibson NW, Spears C P, Danenberg P. (1992) Quantitation of thymidylate synthase, dihydrofolate reductase, and DT-diaphorase gene expression in human tumors using the polymerase chain reaction. Cancer Research. 52: 108-116.

Horn-Ross PL, Hoggatt KJ, West DW, et al. Recent diet and breast cancer risk: the California Teachers Study (USA). Cancer Causes Control 2002,13:407-415.

Hunter DJ, Willett WC. Diet, body size, and breast cancer. Epidemiol Rev 1993,15:110-132.

International Agency for Research on Cancer (IARC). Polynuclear aromatic compounds. In: IARC Monograph on the Evaluation of Carcinogenic Risks to Humans 32. Lyon, France: World Health Organization; 1983.

Katsouyanni K, Trichopoulou A, Stuver S, et al. Ethanol and breast cancer: an association that may be both confounded and causal. Int J Cancer 1994,58:356-361.

Keshava C, Whipkey DL, Weston A. (2002) Transcriptional signature of primary normal human mammary epithelial cells in response to benzo[a]pyrene exposure. Proceedings of the American Assoc. for Cancer Research. 43:1036.

Kumle M, Weiderpass E, Braaten T, Persson I, Adami HO, Lund E. Use of Oral Contraceptives and Breast Cancer Risk: The Norwegian-Swedish Women's Lifestyle and Health Cohort Study. Cancer Epidemiol Biomarkers Prev 2002,11:1375-1381.

Larsen MC, Angus WG, Brake PB, Eltom SE, Sukow KA, Jefcoate CR. (1998) Characterization of CYP1B1 and CYP1A1 expression in human mammary epithelial cells: role of the aryl hydrocarbon receptor in polycyclic aromatic hydrocarbon metabolism. Cancer Research. 58: 2366-2374. 


\section{REFERENCES, continued}

Latil A, Bieche I et. al., (2001) Evaluation of androgen, estrogen (ERa and ERB), and progesterone receptor expression in human prostate cancer by real-time quantitative reverse transcription-polymerase chain reaction assays. Cancer Research. 61:1919-14926.

Li D, Walcott FL, Chang P, et al. Genetic and environmental determinants on tissue response to in vitro carcinogen exposure and risk of breast cancer. Cancer Res 2002,62:4566-4570.

Li D, Wang M, Dhingra K, Hittelman WN. Aromatic DNA adducts in adjacent tissues of breast cancer patients: clues to breast cancer etiology. Cancer Res 1996,56:287-293.

Li D, Zhang W, Sahin AA, Hittelman WN. DNA adducts in normal tissue adjacent to breast cancer: a review. Cancer Detect Prev 1999,23:454-462.

Longnecker MP. Alcoholic beverage consumption in relation to risk of breast cancer: metaanalysis and review. Cancer Causes Control 1994,5:73-82.

Longnecker MP, Newcomb PA, Mittendorf R, et al. Risk of breast cancer in relation to lifetime alcohol consumption. J Natl Cancer Inst 1995,87:923-929.

Longnecker MP, Newcomb PA, Mittendorf R, et al. The reliability of self-reported alcohol consumption in the remote past. Epidemiology 1992,3:535-539.

MacMahon B, Trichopoulos D, Cole P, Brown J. Cigarette smoking and urinary estrogens. N Engl J Med 1982,307:1062-1065.

Martin FL, Carmichael PL, Crofton-Sleigh C, Venitt S, Phillips DH, Grover PL. Genotoxicity of human mammary lipid. Cancer Res 1996,56:5342-5346.

Morris JJ, Seifter E. The role of aromatic hydrocarbons in the genesis of breast cancer. Med Hypotheses 1992,38:177-184.

Nelson HD, Humphrey LL, Nygren P, Teutsch SM, Allan JD. Postmenopausal hormone replacement therapy: scientific review. Jama 2002,288:872-881.

Petralia SA, Vena JE, Freudenheim JL, et al. Risk of premenopausal breast cancer in association with occupational exposure to polycyclic aromatic hydrocarbons and benzene. Scand J Work Environ Health 1999,25:215-221.

Reichman ME, Judd JT, Longcope C, et al. Effects of alcohol consumption on plasma and urinary hormone concentrations in premenopausal women. J Natl Cancer Inst 1993,85:722-727.

Rosenberg L, Metzger LS, Palmer JR. Alcohol consumption and risk of breast cancer: a review of the epidemiologic evidence. Epidemiol Rev 1993,15:133-144. 


\section{REFERENCES, continued}

Rossouw JE, Anderson GL, Prentice RL, et al. Risks and benefits of estrogen plus progestin in healthy postmenopausal women: principal results From the Women's Health Initiative randomized controlled trial. Jama 2002,288:321-333.

Rundle A, Tang D, Hibshoosh H, et al. Molecular epidemiologic studies of polycyclic aromatic hydrocarbon-DNA adducts and breast cancer. Environ Mol Mutagen 2002,39:201-207.

Schernhammer ES, Laden F, Speizer FE, et al. Rotating night shifts and risk of breast cancer in women participating in the nurses' health study. J Natl Cancer Inst 2001,93:1563-1568.

Stevens RG, Davis S, Thomas DB, Anderson LE, Wilson BW. Electric power, pineal function, and the risk of breast cancer. Faseb J 1992,6:853-860.

Stevens RG, Rea MS. Light in the built environment: potential role of circadian disruption in endocrine disruption and breast cancer. Cancer Causes Control 2001,12:279-287.

Thomas HV, Reeves GK, Key TJ. Endogenous estrogen and postmenopausal breast cancer: a quantitative review. Cancer Causes Control 1997,8:922-928.

Tri Reagent - RNA, DNA, protein isolation reagent. Manufacturer's protocol (1995), Molecular Research Center, Inc. Cincinnati, OH.

van't Veer P, Kok FJ, Hermus RJ, Sturmans F. Alcohol dose, frequency and age at first exposure in relation to the risk of breast cancer. Int J Epidemiol 1989,18:511-517.

Willett WC, Rockhill B, Hankinson SE, Hunter DJ, Colditz GA. Epidemiology and assessing and managing risk. In: Diseases of the Breast. Second Edition. Edited by Harris JR, Lippman ME, Morrow M, Osborne CK. New York: Lippincot Williams \& Wilkins; 2000.

Young TB. A case-control study of breast cancer and alcohol consumption habits. Cancer 1989,64:552-558.

Zhang S, Hunter DJ, Hankinson SE, et al. A prospective study of folate intake and the risk of breast cancer. Jama 1999,281:1632-1637. 


\section{APPENDIX A}

\section{Background Readings Considered by the Study Group}

Baker D, Kjellstrom T, Calderon R, Pastides H. Critical Assessment of Environmental Epidemiology Literature. In Baker D, Kjellstrom T, Calderon R, Pastides H. Environmental Epidemiology: A Textbook on Study Methods and Public Health Applications. World Health Organization: Geneva, 1999:247-257.

Bernstein L, Allen M, Anton-Culver H, et al. High breast cancer incidence rates among California teachers: results from the California Teachers Study (United States). Cancer Causes and Control 2002;13:625-635.

The Breast Cancer Fund. State of the Evidence: What is the Connection Between Chemicals and Breast Cancer? 2001:1-18.

Brody JG, Rudel RA, Maxwell N, et al. Breast Cancer and the Environment. Public Health Reports, Silent Spring Institute 1996;3:494-507.

Brody JG, Rudel RA, Melly SJ, et al. Endocrine Disruptors and Breast Cancer. Forum for Applied Research and Public Policy 1998;13:24-31.

Chuang JC, Callahan PJ, Lyu CW, et al. Polycyclic aromatic hydrocarbon exposures of children in low-income families. J Expo Anal Environ Epidemiol 1999;9(2):85-98.

Clarke CA, Glaser SL, West DW, Ereman R, Erdmann CA, Barlow JM, Wrensch MR. Breast cancer incidence and mortality trends in an affluent population: Marin County, California, USA, 1990-1999. Breast Cancer Research 2002;4:R13.

Dos Santos Silva I. Chapter 18. Designing, planning and conducting epidemiological research. In: Dos Santos Silva I. (ed). Cancer Epidemiology: Principles and Methods. Lyon, France: International Agency for Research on Cancer, 1999.

Gammon MD, Neugut AI, Santella RM, et al. The Long Island Breast Cancer Study Project: description of a multi-institutional collaboration to identify environmental risk factors for breast cancer. Breast Cancer Research and Treatment 2002;74:235-254.

Gammon MD, Santella RM, Neugut AI, et al. Environmental toxins and breast cancer on Long Island. I. Polycyclic aromatic hydrocarbon DNA adducts. Cancer Epidemiology, Biomarkers \& Prevention 2002;11:677-685.

Gammon MD, Wolff MS, Neugut AI, et al. Environmental toxins and breast cancer on Long Island. II. Organochlorine compound levels in blood. Cancer Epidemiology, Biomarkers \& Prevention 2002;11:686-697 


\section{APPENDIX A, continued}

Harvey RG. Environmental occurrence and cancer. In: Polycyclic Aromatic Hydrocarbons: Chemistry and Carcinogenicity. Cambridge University Press, 1991:11-25.

Horn-Ross PL, Hoggatt KJ, West DJ, et al. Recent diet and breast cancer risk: the California Teachers Study (USA). Cancer Causes and Control 2002;13:407-415.

Kelsey JL, Bernstein L. Epidemiology and prevention of breast cancer. Annu Rev Public Health 1996;17:47-67.

Kogevinas M, Pearce N, Susser M, Boffetta P (eds.). Social Inequalities and Cancer. Lyon: International Agency for Research on Cancer (IARC), 1997. IARC Scientific Publication No. 138.

Kuller LH. The etiology of breast cancer-from epidemiology to prevention. Public Health Rev 1995;23(2):157-213.

Lane-Claypon JE. A further report on cancer of the breast with special reference to its associated antecedent conditions. Report on Public Health and Medical Subjects, No. 32. London: Ministry of Health. His Majesty's Stationery Office, 1926.

Li D, Walcott FL, Chang P, et al. Genetic and environmental determinants on tissue response to in vitro carcinogen exposure and risk of breast cancer. Cancer Res 2002;62(16):4566-70.

Maxwell N, Brody JG, Melly SJ, et al. Newton Breast Cancer Study. Silent Spring Institute, 1999.

Maxwell N. Social differences in women's use of personal care products: A study of magazine advertisements, 1950-1994. Silent Spring Institute, 2000:1-13.

Moffatt S, Mulloli TP, Bhopal R, Foy C, Phillimore P. An exploration of awareness bias in two environmental epidemiology studies. Epidemiology 2000;11:199-208.

Quackenboss JJ, Pellizzari ED, Shubat P, et al. Design strategy for assessing multi-pathway exposure for children: the Minnesota Children's Pesticide Exposure Study (MNCPES). J Expo Anal Environ Epidemiol 2000;10(2):145-58.

Reid SE, Murthy MS, Kaufman M, et al. Endocrine and paracrine hormones in the promotion, progression and recurrence of breast cancer. Br J Surg 1996;83(8):1037-46.

Rothenberg RB, Steinberg K, Thacker S. The public health importance of clusters: A note from the Centers for Disease Control. American Journal of Epidemiology 1990:132, Suppl. (1):S3-S5.

Rothman KJ. A sobering start for the cluster busters' conference. American Journal of Epidemiology 1990;132, Suppl.(1):S6-S13. 


\section{APPENDIX A, continued}

Rothman KJ, Poole C. Chapter 1. Causation and causal inference. In: Schottenfeld D \& Fraumeni JF (eds). Cancer Epidemiology and Prevention. Second Edition. New York: Oxford University Press, 1996.

Rothman KJ, Greenland S. Chapter 2. Causation and causal inference. In: Rothman KJ \& Greenland S (eds). Modern Epidemiology. Second Edition. Philadelphica: Lippincott-Raven Publishers, 1998.

Rothman KJ. What is Causation? In: Epidemiology: An Introduction. New York, NY: Oxford University Press, 2002:8-23.

Rudel RA. Predicting health effects of exposures to compounds with estrogenic activity: methodological issues. Environ Health Perspect 1997;105(3):655-63.

Rudel RA, Melly SJ, Geno PW, et al. Identification of alkylphenols and other estrogenic phenolic compounds in wastewater, septage, and groundwater on Cape Cod, Massachusetts. Environ Sci Technol 1998;32:861-869.

Silent Spring Institute. The Cape Cod Breast Cancer and the Environment Study. 1997:1-29.

Thomas DB, Karagas MR. Chapter 12. Migrant Studies. In: Schottenfeld D \& Fraumeni JF (eds). Cancer Epidemiology and Prevention. Second Edition. New York: Oxford University Press, 1996.

Vineis P, Malats N, Lang M, d'Errico A, Caporaso N, Cuzick J, Boffetta P (eds.). Metabolic Polymorphism and Susceptibility to Cancer. Lyon: International Agency for Research on Cancer (IARC), 1999. IARC Scientific Publication No. 148.

Welp EA, Weiderpass E, Boffetta P, et al. Environmental risk factors of breast cancer. Scand J Work Environ Health 1998;24(1):3-7.

Willet WC. Epidemiology and Nongenetic Causes of Breast Cancer. Diseases of the Breast. J. R. Harris. Philadelphia, Lippincott, Williams, \& Wilkins, 2000:175-220.

Willett WC. Balancing life-style and genomics research for disease prevention. Science 2002;296(5568):695-8.

Yost K, Perkins C, Cohen R, et al. Socioeconomic status and breast cancer incidence in California for different race/ethnic groups. Cancer Causes Control 2001;12(8):703-11. 


\section{APPENDIX B}

\section{Two Examples of Workshop Maps}




\section{APPENDIX B, $1^{\text {st }}$ Workshop Map Example}

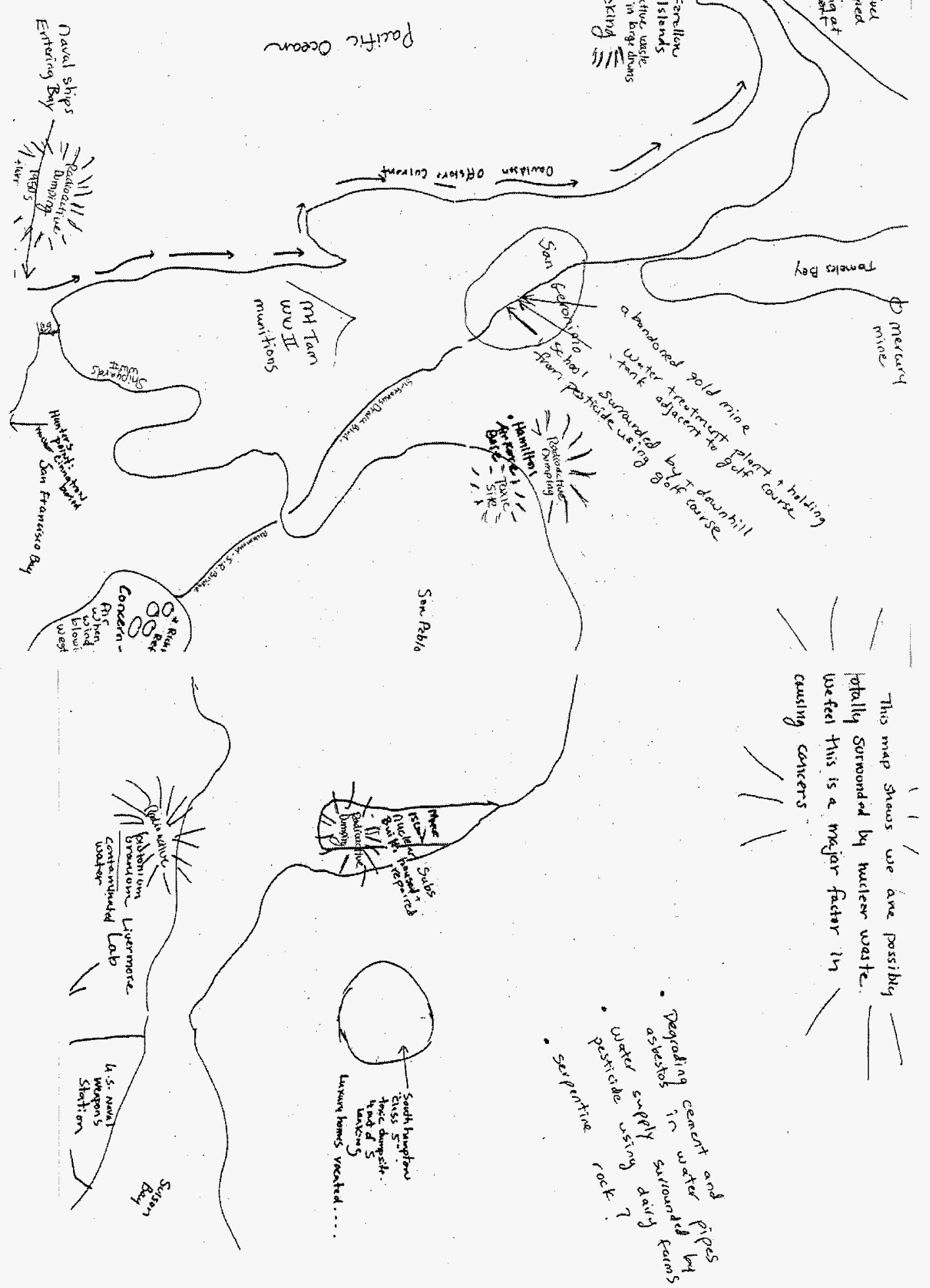




\section{APPENDIX B, 2nd Workshop Map Example}

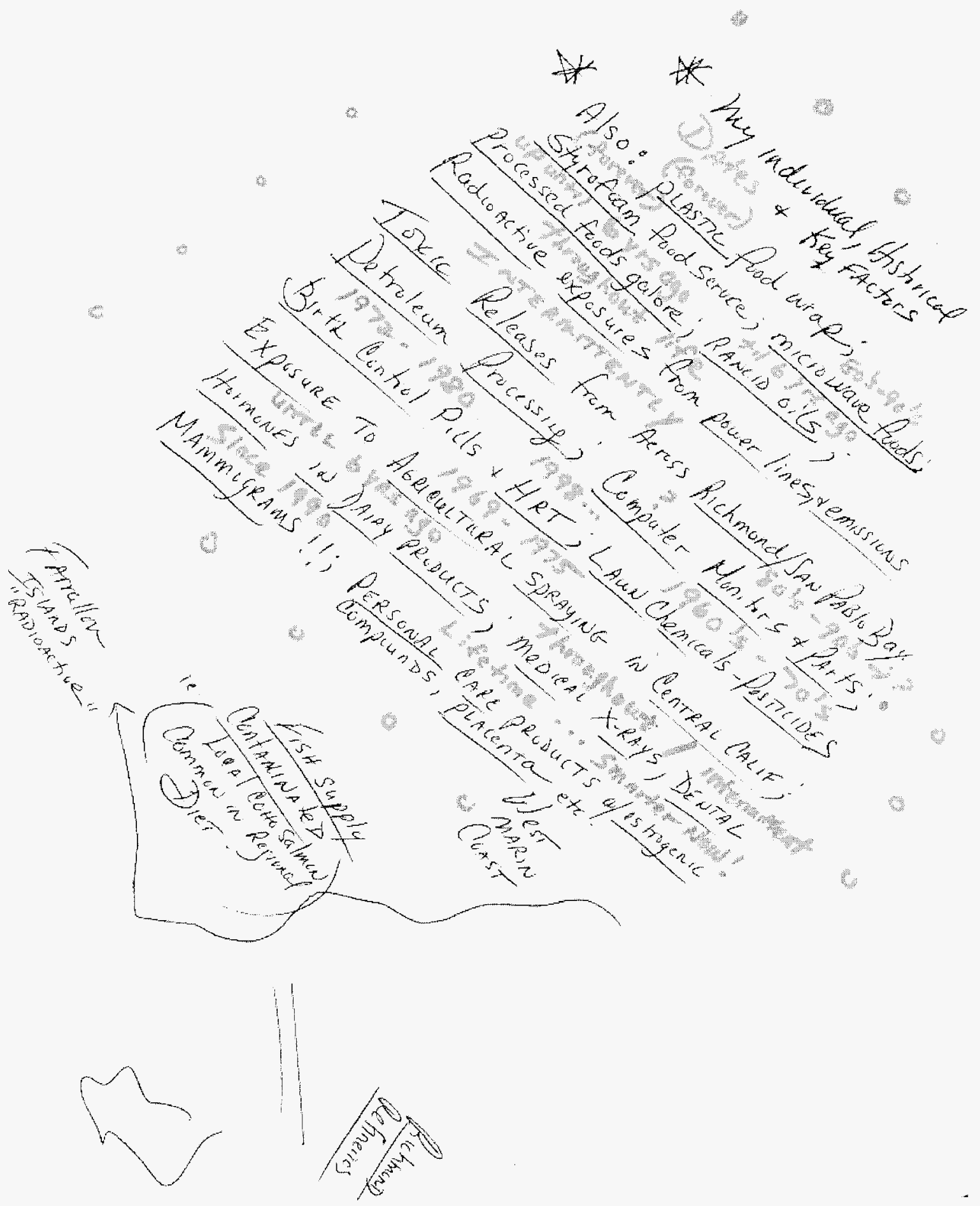

